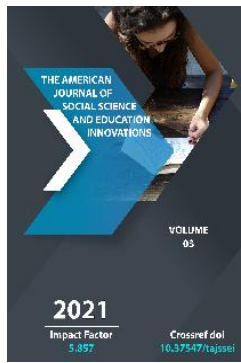

\title{
Hypertextuality Of Tolstoy's Prose
}

\author{
Xushnudabonu Ilhomjon Qizi Ziyayeva \\ Teacher, Kokand State Pedagogical Institute, Uzbekistan
}

Journal Website:

http://theamericanjour

nals.com/index.php/taj

ssei

Copyright: Original content from this work may be used under the terms of the creative commons attributes 4.0 licence.

\section{ABSTRACT}

This article highlights the intersection of realism and postmodernism of the 2oth century and the hypertextuality of Tatiana Tolstoy's prose. The purpose of the article is to study the poetics of mythological prose, methods and forms of mythologization in modern Russian prose. The scientific novelty lies in the fact that this article seeks to consistently explore not only the myth, but also the mechanisms of mythologization and demythologization in Tolstoy's prose, as well as to identify the axiological and ontological features of mythology in the writer's texts. The theoretical significance of the article consists in the further development of theoretical knowledge about the categories of mythopoetics, the deepening of ideas about the mythologism of literature and the genre features of the mythological novel. The practical significance of the article lies in the fact that its materials can be used in lecture courses and seminars on the history of modern literature, the theory of myth, as well as in the works on T. N. Tolstoy.

\section{KEYWORDS}

Hypertextuality, mythologization, demythologization, mythopoetics, mythologism, realism, postmodernism, intertextuality, Kys, Old Russian alphabet, intertext, traditionality, unconventionality, intervlection, metatext.

\section{INTRODUCTION}

The intersection of realism and postmodernism creates "the most complex aesthetic effects, striking in their unconventionality even in cases where the orientation to tradition" is declared. In this sense, the novel by T. Tolstoy "Kys" is 
characteristic, where you can see almost all the features of postmodernism, where the reader can feel in another world, as if in a mirror.

The main feature of the novel "Kys" is its intertextuality. This was written by $B$. Paramonov, A. Nemzer and others. In the novel "Kys" T. Tolstaya used all forms of intertextuality, which are manifested in three aspects: 1) in the genre of the novel; 2 ) in the appeal to different forms of folklore; 3 ) in the reflection of intertextual borrowing in the language plan. Tolstoy's novel is deeply intertextual: the use of elements of the "known" plot, the reworking of the theme, allusions, explicit and hidden citations, reminiscences, parody, borrowing and other techniques exist in it.

T. Tolstaya creates an extraordinary fairy-tale world: legends, folk tales, etc. Intertextuality is also embodied in the language of the novel, which combines high, neutral and colloquial styles of speech. According to N. Ivanova, in the novel "the author's speech is deliberately displaced by the words of the characters": "With Benedict in the Working Hut and other scribes sit side by side. Olenka, my dear, draws pictures. The girl is pretty: her eyes are dark, her braid is fair, and her cheeks - like the evening dawn, when we expect the wind to blow by the morning-are glowing. Eyebrowsan arch, Ali, as now it will be led to call, a rocker: a rabbit fur coat, felt boots with solesprobably a noble family<>How will you approach Olenka? Benedict just sighs and looks sideways, and she knows, honey, that she'll blink her eyes and twitch her head. Modest girl."

Monster words are not uncommon, such as felasofia, oneverstetskre, abrazavanie, rinisansi, etc., words-fragments of the "old language" (the language of the educated).
The speech of the work is very unusual, folklore-fairy-tale, in which simple sentences and inversion are often used. This is the syntax of Russian folk folklore. N. Ivanova believes that "the syntax is excited, running, singing, everyone, except for the orderly-sadgrammatical correct": "So, you run past their settlement, throw something like that-and into the quagmire. For a week, the rust has grown fresh, reddish, as if with green. It's good to smoke it. And the old one will be browner, the one on the paint or on the braga is more used. Here in a dry leaf of fine rust you will fence".

The novel " Kys "differs from other works with the use of the letters of the Old Russian alphabet for the titles of chapters: "Az", "Buki", "Vedi", "Glagol" and others. This was stated by B. Paramonov, " TatyanaTolstaya wrote - created - the most real model of Russian history and culture. A working model. Microcosm".

The integrity of the novel by T. Tolstoy is obviously manifested, first of all, in the stylistic plan. The novel "Kys", as well as other works of T. Tolstoy, are united by one stylistic manner. As B. Paramonov notes: "Tatiana Tolstaya not only changed her manner, far from it, but expanded it into a large form: she wrote a novel."

Intertext is the main method of creating text in postmodern literature. According to I. I. llyin, "every text is a 'reaction' to previous texts." The literary critic M. L. Malakhovskaya understands with intertextuality: "the presence in the text of elements that, due to the author's purposeful strategy or regardless of his intention, activate in the reader's mind other texts that he has read before." In his book "Palimpsests: literature in the second degree" (1982), the French literary critic Gerard Genette defines hypertextuality as a 
type of text interaction, interpreting someone else's text as mockery or parody.

One of the most common signs of hypertext in Tolstoy's short prose is the presence of such elements as parody and variation. According to $M$. Bakhtin, " variation freely introduces foreign-language material into modern themes, combines the stylized world with the world of modern consciousness, puts the stylized language, testing it, in new and impossible situations for itself." When it comes to parody, it's based on "the idea of doubling down, i.e. introducing a laughable aspect alongside the tragic one."

The most striking places in this regard are the hypertexts representing the clothes of the most famous hero of the collection "Not cut" to the story "Fakir" by I. Goncharov Ilya Oblomov. Among them are a hoop, a robe and shoes. In Tolstoy's text, these are "a small hand heavy with a ring", "a crimson robe with tassels" and "silver Janissary slippers with curved noses" and under the pretext - "a large massive ring with some dark stone", "a robe of Persian cloth, without the slightest hint of Europe, without tassels, without velvet, without a waist, very spacious" and "long, soft and wide shoes".

Another hypertextual inclusion is Filin's parody retelling of the love story of the great Johann Wolfgang Goethe for the young Ulrika von Levetzow: "When Goethe fell in love with the young, charming Ulrika as an old man and had the imprudence to woo, he was rudely refused. From the doorstep. Or rather, from the window. The charmer leaned out of the window and barked at the Olympian... the old one, they say, and there too. Faust looked around. Fish should be eaten more - there is phosphorus in it, so that the head cooks. Einmal in der vohe-fish! And she slammed the window shut." This part performs the function of metatext: the reader identifies the predefined text using a preposition, and acts as a source of bias to it.

The story of the Poet and Moses is a parody created to create a comic effect for the reader, repeating the specific features of an already known work in a specially modified form. For example, in the text under study, the author describes the direction of the picture, called " quote»: "To make her canvases, Lizaveta, like an African sorcerer, had to bring herself into an unbridled rage, and then a fire would light up in her dull eyes, and with screams, wheezes, with a kind of dirty anger, she would attack and knead the blue, black, and yellow colors on the canvas with her fists, and immediately scratch the oil porridge with her nails." Apparently, this name was created as a result of the similarity with the "- isms " that already exist in art: impressionism, Marinism, symbolism, Cubism, and so on. In the history of "Yesterday" we find a stand with two nails by A. S. Pushkin "Winter Evening". If in the first case the author's text does not undergo the metamorphoses pronounced by his mother, in the second case the poetic stanza retains its sound shell: the mind of Alexey, a boy with dementia, hypertrophy, repeats their phonetic image, ignoring semantics and syntax:

"Buryam, gloyu, nebak, digs, Whirl, be gentle, ekru, cha! Tokag, zverya, naza, howls, Toza, cries, kagdi, cha!".

This poetic play performs an expressive function in the text, informing about the cultural and semiotic places of the author of the story: "The traditions of language play, travestirovaniya - this is Pushkin! But not Pushkin's odes "Liberty" or "Monument", but 
Pushkin-the author of epigrams, "Gavriiliad", "Tsar Nikita..." and others.

In the story "Love - do not love" there is a variation of the poem by A. Pushkin "Nanny": the famous "My old dove!" - "My fat pig!" becomes a mocking design. In this sense, such a text expresses his point of view, using the words of others instead of the text: "But he (Pushkin) did not write anything about Marywanna. Even if he wrote it: "My fat pig!". In the story of "Yorick" there are various poetic verses by A. The block of "Strangers": "... the grandmother safely spun, carrying under her breast, or on her waist, fragments of the seas, pieces of a delicate gray-pink mouth, and passed through the enfilades of rooms, slender and small, decadent Aphrodite with a heavy knot of dark gold hair, rustling silks and breathing French perfume and fashionable Norwegian mists."

In the essay "The Russian man at the rendezvous" there is often a variation of the famous line from the comedy "Woe from Wit" (1824) by A. S. Griboyedov, which is a kind of cultural mythologem of Russia: "The Fatherland and the smoke is sweet and pleasant to us". These are the words of Chatsky (act. 1, Yavl. 7): "I am destined to see them again! I will get tired ofliving with them, and in whom you will not see spots?

When you travel, you will return home,And the smoke of the fatherland is sweet and pleasant to us."Griboyedov, in his play, quoted a line from the poem "Harp" (1798) by GavrilaRomanovich Derzhavin:

"The good news about our side is sweet to us. The smoke of the Fatherland is sweet and pleasant to us."

In the essay "The Russian man at the rendezvous" there are intervinclusions in the form of variations of A. P. Chekhov's lines and sayings of different times and peoples: "... all hung guns shoot in due time; all roads lead to Rome, all languages-to Kiev...". In the finale of the essay there is a somewhat transformed line from the poem "Cicero" (1836) Fyodor IvanovichTyutchev: Russian Russian writers, we Russians who have "visited this world in its fateful moments" (they are always inevitably fatal for us), see how the fate of one of us is shaping up in the next round of Russian history, in the next round of the fate of Russian literature. Such elements give the narrative a journalistic quality, adding connotative color.

Another discovered hypertext is a variation of the famous phrase of $\mathrm{A}$. N. Ostrovsky in the comedic title "For every wise man there is enough simplicity" in the essay "The Battle of the shrimp with the grouse": "I want every cunning shrimp to find a cancer with a screw." To emphasize that Russia depends on the traditions of original consumers, T. Tolstaya proposed an alternative to mushrooms in the form of mushrooms "real, forest, with a leaf stuck to the cap and an unshaven leg, like Leonid Parfenov's chin."

Thus, we found that the intertextuality of T. N. Tolstoy's short prose is a stylistic tool that allows us to give an artistic image to a literary work through transformation. Note that reading hypertext work is a form of postmodernism. The reader generates and modifies a sequence of events, which leads to a constant increase in the values of the source text.

\section{REFERENCES}

1. L. Andreev. Barely the threshold of the coming y. literatures. // 1987g. No. 8-p. Thirty-five. 
2. Ivanova N. And

stillkakletovizrubyaptitsupaulin. - Hello "Znamya", 2001, No. 3.

3. T. Tolstoy. From Kama. - M., 2001. - p. 108.

4. Natal Ivanov. And how to cut down the bird Pauline. - Hello "Znamya", 2001, No. 3.

5. B. Paramonov. Finally vindicated the literature of $\mathrm{V}$. the history of Russian culture. - TIME-MN. 14.10.2000.

6. I. Ilyin.I. Intertextuality // Sovremennoliteraturovedenie (USA and Western countries of Europe): kontseptsii, shko, terminii. Encyclopedia reference book. - M., 1999.

7. Malakhovskaya M. L. Svyazam i khudozhestvennom kontraktivno teksty intertextualny $\quad \mathrm{v}$. v.-aspekty perevodovedcheskom (K. still materialy produkenimi S. Lewis). Avtoreferat. kand. phil. naukom. S. - Pb., 2007.

8. M. Bakhtin. M. Estetikii. Voprosyliteratury. - M.: Khudozhestvennaya literatura, 1975.

9. O. Freudenberg. M. The origin of parody // Literature of the XX century. zerkaleparodii Russian tel: Anthology / Comp., intro. st., st. k. sec., comment. Exactly.B. Kushlinoy. - M., 1993.

10. T. Tolstoy.N. Ni k gorod. - M.: Eksmo, 2011.

11. L. Gruzberg. Paradox / / Philolog. - 2003. No. 3 . 